TUL區 $\mathbb{S} \mathbb{X} \mathbb{A} \mathbb{I} L \mathbb{A}$ 



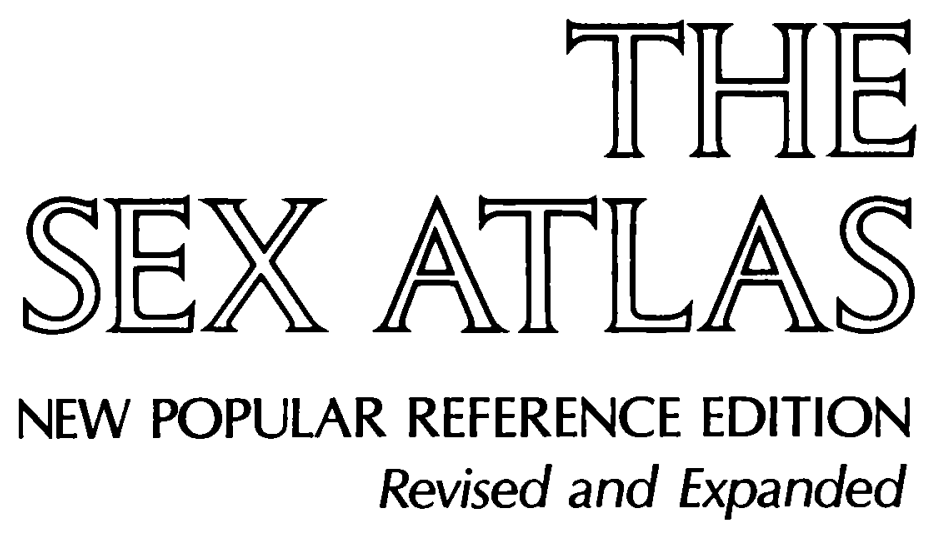

ERWIN J. HAEBERLE, Ph. D. , Ed. D. 


\section{PICTURE CREDITS}

Special acknowledgment is made to Laird Sutton, Ph.D., for the majority of photographs that appear in this book, and to Liz Green for the technical illustrations. The author also wishes to acknowledge the following sources for pictures:

Linda Frederickson $18,19,21,22,23 \quad$ Vincent Defeo 41

Carnegie Embryological Collection, University of California, Davis 84,85

Tom Sikes 95, 96 Honey Lee Cottrell 111 Linda Frederickson $170 \quad$ Phototrends 274

Edward Hyde, Lord Cornbury: The New York Historical Society; George Sand: New York Public Library

Picture Collection; The Chevalier d'Eon: The Mansell Collection 291

The Granger Collection 300

Ancient Roman sculpture of Amazon in combat: New York Public Library Picture Coilection 302

The Granger Collection $304 \quad$ New York Public Library Picture Collection 327

Koninklijk Museum, Antwerp $331 \quad$ New York Public Library Picture Collection 335

Staatliches Museum für Völkerkunde, München 338

Hammurabi: Bildarchiv Preussischer Kulturbesitz, Berlin; Moses and Mohammed: New York Public Library Picture Collection $356 \quad$ Culver Pictures 435

Swiss middle-class family in 1559: Hans Kluber, Familienbild, Kunstmuseum, Basel; American middle-class

family in the 19th century: Historical Society of Pennsylvania 450

Family life in the 17th century: Staatliches Museum für Völkerkunde, München; Family life in the 19th century: New York Public Library Picture Collection 453

Female chastity belt: Historia-Photo, Bad Sachsa, West Germany 465

Sappho, Sophocles, Plato, Alexander the Great, Richard I, Leonardo da Vinci, Montezuma II, James I of Eng-

land, von Humboldt, Cogol, Whitman, Alger, Saint-Saëns, Tchaikovsky, McDonald, Rimbaud, Proust: The

Granger Collection; Julius Caesar, Edward II, Michelangelo, Henry III: Culver Pictures; Gide, Maugham,

Stein, Keynes, Nicolson: Wide World; Garcia Lorca: Embassy of Spain, Washington, D.C.; Auden: Patrick

Burns/New York Times Pictures 476, 477, 478

Sigmund Freud and Havelock Ellis: The Granger Collection; Iwan Bloch, Sexology Magazine; Magnus Hirschfeld: Wide World 496

The Hymn Book of the Anglican Church of Canada and the United Church of Canada 525

\section{3}

The Continuum Publishing Company

575 Lexington Avenue

New York, N.Y. 10022

Copyright $\odot 1981$ by Erwin J. Haeberle.

All rights reserved. No part of this book may be reproduced, stored in a retrieval system, or transmitted in any form or by any means, electronic, mechanical, photocopying, recording, or otherwise, without the written permission of The Continuum Publishing Company.

Library of Congress Cataloging in Publication Data

Haeberle, Erwin J.

The sex atlas.

Bibliography: p. 531

Includes index.

1. Sex. 2. Sex (Psychology) 3. Sex role.

4. Sexual deviation. 5. Sexism.

II. Title.

HQ12.H33 $1981 \quad 612 ' .6 \quad 81-12604$

ISBN 0-8264-0178-3 AACR2

ISBN 0-8264-0057-4 (pbk.) 